\title{
Active emergence of meiofauna from intertidal sediment
}

\author{
Werner Armonies
}

Biologische Anstalt Helgoland (Litoralstation), D-2282 List, Federal Republic of Germany

\begin{abstract}
Laboratory experiments were conducted to test for active meiofaunal emergence from intertidal sediment in the absence of currents. Copepoda, Ostracoda, Plathelminthes and Polychaeta actively left submerged glass jars containing undisturbed sandy sediment. Ostracoda and juvenile Bivalvia moved to the sediment surface and climbed out of the glass jars while other taxa left the jars by swimming. In no case did Nematoda or Oligochaeta leave the sediment. During a single nocturnal high tide, $87 \%$ of Copepoda, $67 \%$ of Ostracoda and $42 \%$ of Plathelminthes may leave the sediment. Emigration rates are significantly smaller during diurnal high tides. Copepoda were randomly distributed in the water column 10 to $50 \mathrm{~cm}$ above the bottom and Plathelminthes between 10 and $40 \mathrm{~cm}$. There are specific differences in the emigration rates of plathelminth taxa. Diatom-feeders, copepodfeeders and unspecific predators emerged in significantly higher proportions than did nematodefeeders and bacteria-feeders. Results suggest high mobility and high transport rates of intertidal meiofauna above the sediment.
\end{abstract}

\section{INTRODUCTION}

Although meiobenthos was traditionally thought to be strictly infaunal, recent investigations report on meiofaunal occurrence in the water column (e. g. Alldredge \& King 1977, 1980, 1985, Porter \& Porter 1977, Hobson \& Chess 1979, Hammer 1981, McWilliam et al. 1981, Sibert 1981, Ohlhorst 1982, Youngbluth 1982, Fancett \& Kimmerer 1985, Hicks 1986, Walters \& Bell 1986). Studies on recolonization of experimentally disturbed sediment and short-term meiobenthic surveys often yield indirect evidence for meiobenthos dispersing via the water column (e. g. Bell \& Sherman 1980 , Sherman \& Coull 1980, Thistle 1980, Hockin \& Ollason 1981, Palmer \& Brandt 1981, Chandler \& Fleeger 1983, Fleeger et al. 1984, Kern \& Bell 1984). No regular emergence was found in the studies of Hagerman \& Rieger (1981), Palmer (1984) and Palmer \& Gust (1985), all of which were performed with muddy sediments. They concluded that the occurrence of meiobenthos in the water column is a passive process caused by erosion. In contrast most of the studies assuming active emigration of meiobenthos derived from sandy sediment or seagrass meadows. However, with the exception of Sibert (1981) and Hockin \& Ollason (1981) all the above studies deal with tropical to warm-temperate habitats, and direct evidence for meiobenthos entering the water column has up to now been restricted to subtidal areas.

In boreal intertidal and supratidal sand, meiobenthos performs more or less regular tidal vertical migrations in the sediment (Meineke \& Westheide 1979). When the sand is disturbed by turbulence in the overlying water the majority of the fauna responds by downward migration (Boaden 1968); only various Copepoda and Plathelminthes move upward (Boaden \& Platt 1971). Downward movement will reduce the risk of being suspended, and upward migrations will enhance suspension-rates. In muddy sediment, water flow causes only minor differences in the vertical pattern of meiofauna (Palmer \& Molloy 1986) but above-ground structure (Spartina culms) may enhance copepod emergence under some hydrodynamical conditions (Palmer 1986).

The aim of this study was to investigate the rates of zoobenthos actively emerging from boreal intertidal sandy sediment. The passive component of meiobenthic occurrence in the water column was experimentally excluded - though not denied. Active emigration from the sediment may be a means of meiofaunal dispersal (Gerlach 1977, Alldredge \& King 1980, Bell \& Sherman 1980) but may also offer additional prey 
(Decho 1986). On the other hand, meiofauna leaving the sediment may itself be subject to increased predation (Hobson \& Chess 1976, Fulton 1982, Ohlhorst 1982). In many cases it is not known whether predators on meiofauna catch their prey in the water column, at the sediment surface, or by burrowing (e. g. Zander \& Hartwig 1982, Sogard 1984).

\section{MATERIAL AND METHODS}

Sampling. For all experiments, samples were collected from a $30 \times 30 \mathrm{~m}$ plot of the Königshafen wadden area near the Island of Sylt (North Sea). For a general description of the area see Reise (1985). The plot is rather sheltered and the sediment is mainly composed of medium sand (median diameter of sand grains $315 \mu \mathrm{m}$, sorting coefficient 1.5) with moderate amounts of detritus (loss on ignition $0.48 \%$ ). Experiments were performed between May and July 1987 Seawater temperature in May was $12{ }^{\circ} \mathrm{C}$ and increased to 15 to $16^{\circ} \mathrm{C}$ in July. Air temperature varied between 10 and $20^{\circ} \mathrm{C}$. The sampled plot is positioned at mid-tide level (50\% tidal emersion); average tidal range is about $1.8 \mathrm{~m}$ in this area and about $0.9 \mathrm{~m}$ at the plot.

Sediment samples were collected with glass or plastic tubes to a depth of $2.5 \mathrm{~cm}$. All experiments were simultaneously conducted in 10 aquaria (10 parallels) Samples were collected during low tide, about 2 h before the sample site was again flooded by the sea. These $2 \mathrm{~h}$ were used for transport to the laboratory and sample preparation. Thus the experimental submersion started at the same time as the sample site was flooded in the field.

Experimental treatments and null hypotheses. Experiment I: Do meiobenthos actively leave the sediment? Plastic aquaria (24 cm long and $12 \mathrm{~cm}$ wide) were filled with $2 \mathrm{l}$ of filtered seawater and stored for $24 \mathrm{~h}$ to adapt to the experimental temperature of $12{ }^{\circ} \mathrm{C}$ (= actual field temperature). Ten samples of $2 \mathrm{~cm}^{2}$ surface area were collected at each of 5 sites and transferred into $10 \mathrm{~cm}^{3}$ glass jars. In the laboratory, jars were cautiously filled with $12^{\circ} \mathrm{C}$ filtered seawater without agitating the surface of the samples. Five samples (one from each site) were subsequently submerged into each of the 10 aquaria. For the next $4 \mathrm{~d}$, benthos could emigrate from the sediment and swim or climb into the aquaria. To record the course of emigration, the jars were transferred to a second set of aquaria after fixed periods and the water of the previously used aquaria poured through $63 \mu \mathrm{m}$ meshes to retain emigrated fauna.

With modification of the light regime, the experiment was repeated 3 times: Expt Ia was performed in con- tinuous light $\left(50 \mu \mathrm{E} \mathrm{m} \mathrm{m}^{-2} \mathrm{~s}^{-1}\right)$ with water exchange every $24 \mathrm{~h}$. Expt Ib was performed in continuous darkness except when transferring the glass jars into a new set of aquaria which was done every $24 \mathrm{~h}$. Finally, Expt Ic was performed under a $18 / 6 \mathrm{~h}$ day/night rhythm with water exchange every $6 \mathrm{~h}$

Expt I tested the following hypotheses:

$H_{0}$ (1): There is no active emigration of benthos from the sediment - faunal abundance in the experimental aquaria does not significantly differ from zero.

$\mathrm{H}_{\circ}(2)$ : Emigration is random in time - the rates of emigrating fauna do not differ among the $4 \mathrm{~d}$ of experimentation

$H_{0}(3)$ : There are no differences in the percentage emigration rates between taxa - all taxa behave the same.

Experiment II: Percentage emigration during one tidal cycle of submersion. Experimental design was as Expt I, with 2 exceptions: (1) smaller aquaria were used $\left(400 \mathrm{~cm}^{3}\right.$ seawater instead of $2000 \mathrm{~cm}^{3}$ ) and only one glass jar with sediment was submerged per aquarium; (2) glass jars containing the sediment were transferred to a new set of aquaria at $1 \mathrm{~h}$ intervals (total $6 \mathrm{~h}$ ). The size of sediment samples was $1 \mathrm{~cm}^{2}$ surface area, sampled to a sediment depth of $2.5 \mathrm{~cm}$. Expt II was performed twice: Expt Ila during daytime, with light (50 $\mu \mathrm{E} \mathrm{m}^{-2} \mathrm{~s}^{-1}$ ), and Expt IIb during night-time, in the dark. It tested the hypothesis

$\mathrm{H}_{\mathrm{o}}(4)$ : The pattern of emergence is random over time $(6 \mathrm{~h})$.

Experiment III: Distance meiobenthos swims above bottom. The previous experiments monitored the rate of benthos leaving the sediment, either swimming or climbing out of the jars. Expt III only recorded actively swimming benthos and tested the hypothesis $\mathrm{H}_{0}(5)$. There is no difference in the abundance of swimming benthos between 10 and $50 \mathrm{~cm}$ above bottom.

Ten plastic barrels $(34 \mathrm{~cm}$ in diameter and $57 \mathrm{~cm}$ high) were filled with filtered seawater to a height of $55 \mathrm{~cm}$. As a source of swimming benthos, 3 Petri dishes containing $60 \mathrm{~cm}^{2} \times 1 \mathrm{~cm}$ surface sediment were submerged into each of the barrels. These dishes were initially filled with filtered seawater to the rim, any material adhering to the water surface was removed by slight decantation, the dishes were again filled with seawater and finally cautiously submerged into the barrels. Five plastic boxes of $500 \mathrm{~cm}^{3}$ volume were submerged into each barrel without contact to the ground or side walls. There was no possibility of entering the boxes other than by swimming. The upper rim of the boxes were $10,20,30,40$, and $50 \mathrm{~cm}$ above ground, respectively. Boxes were removed after $6 \mathrm{~h}$ storage in the dark and their water content sieved through 63 mm meshes to retain swimming benthos. 
Experiment IV: Specific composition of emigrating and non-emigrating Plathelminthes. Fewer species were recorded as active emigrators in the previous experiments than are normally found in the sampled tidal flat. Expt IV checked for specific differences in the plathelminth emergence pattern. It tests the hypothesis $\mathrm{H}_{\mathrm{O}}(6)$ : There is no difference in the rates of emigration between plathelminth species (subordinated taxa, feeding types).

No extra experiments were performed to check for this point. Instead, the species composition of Plathelminthes emerging in Expt Ib was compared to the species composition of non-emigrators.

Test of experimental methods. Sediment sampling causes at least slight mechanical disturbance of the sediment structure. Meiofaunal behavior might be influenced by these disturbances, resulting in artifacts in the experiments outlined above. The effect of mechanical disturbance on meiofaunal emigration was tested using experimental designs like Expt II on 6 levels of mechanical disturbance

(1) Sampling tubes were closed at the bottom and directly used in experiments - no transference into glass tubes.

(2) 'Normal sampling': cores were sampled with plastic tubes and transferred into glass tubes for transport and experimentation - slight deformation of the sediment structure.

(3) 'Normal sampling' + mechanical stirring of the sediment.

(4) 'Normal sampling' + destruction of the sediment structure by shaking of the glass containers.

(5) 'Normal sampling', but the sediment column was turned upside down.

(6) Combination of (3) and (4) to completely destroy the sediment structure.

With the exception of Plathelminthes which left the sediment turned upside down at significantly higher rates( $U$-test, $p<0.001$ ) when compared to (1) and (2), the above treatments did not affect emigration rates in the previously described experimental design. However, this does not mean that meiobenthos might not generally be susceptible to this kind of disturbance. To avoid inadmissible generalization beyond the level of this study, I will not present any further data. They can be obtained on request.

Statistical treatment. In general, abundance data differ significantly from a normal distribution. Therefore, the non-parametrical $U$-test (Wilcoxon et al., in Sachs 1984) is used throughout as a conservative measure. Significant results are indicated by $(p<0.05)$, $\cdots(p<0.01)$ and $\cdots(p<0.001)$. The standard deviation given in the tables does not intend to describe the data distribution but is used to indicate the range of variability.

\section{RESULTS}

Taxonomic composition of the metazoan benthos at the sampled plot

Ten sediment samples of $2 \mathrm{~cm}^{2}$ surface area 10 to $2.5 \mathrm{~cm}$ layer) were randomly collected at the sample site (20 June 1987). Grain-by-grain sorting of these samples (without fixation) yielded an average of 1906 metazoans below $10 \mathrm{~cm}^{2}$ surface area. Nematoda were most abundant $\left(990\right.$ ind. $10 \mathrm{~cm}^{-2}=51.8 \%$ of metazoan benthos), followed by Copepoda (520 ind. $10 \mathrm{~cm}^{-2}=$ $27.2 \%)$, Ostracoda (198 ind. $\left.10 \mathrm{~cm}^{-2}=10.4 \%\right)$, Polychaeta $(4.1 \%)$, Oligochaeta $(3.5 \%)$, and Plathelminthes $(2.7 \%)$. Other taxa, such as Gastrotricha, Gnathostomulida and Halacarida were present but together supplied $<1 \%$ of metazoans.

\section{Experiment I: Do meiobenthos actively leave the sediment?}

Copepoda, Ostracoda and Plathelminthes left the sediment in significant numbers in all 3 trials of Expt $I$. The number of emigrating Polychaeta was significantly different from zero only in the continuously dark and the day/night-rhythm trials. No significant emigration was found in Nematoda and Oligochaeta in either case, although they are major components of the benthos at the sampled site. Veliger-larvae of Littorina littorea L. and juvenile Bivalvia (mainly Cerstoderma edule [L.]) also emigrated from the sediment. Veliger-larvae behaved similarly to Copepoda and juvenile Bivalvia behaved like Ostracoda. Both groups are however not mentioned further.

Sorting of the sediment after $4 \mathrm{~d}$ of submersion was performed on all 50 samples of Expts $\mathrm{Ib}$ and on 10 randomly chosen samples of Expts Ia and Ic. The corresponding numbers of animals that remained in the sediment allow for an estimate of the percentage of emigrated specimens (Table 1). Though the 3 trials were not simultaneously performed and are thus not adequate to test for the influence of light, the percentages indicate higher activity during darkness. This is also seen in the periodical increase of emigrating benthos in Expt Ic (Fig. 1). Significantly more specimens emigrated in the dark period than in the light. However, such a pattern might also be caused by an endogenous diurnal rhythm.

Since the number of emigrating benthos seems to be increased by continuous darkness and decreased by continuous light, Expt Ic with an $18 / 6 \mathrm{~h}$ day/night rhythm is most appropriate to judge on the mobility of benthos (Table 1). The percentage of Copepoda leaving the sediment during the first days, however, is too 
Table 1. Abundance of emigrated fauna in Expts Ia ( 1 , light), Ib (d, darkness) and Ic (l/d, light/darkness), and average number of specimens that remained in the sediment. Total: sum of emigrated fauna (within $96 \mathrm{~h}$ ) and fauna that remained in the sediment. $\overline{\mathrm{x}}$ : mean; SD: standard deviation; \%: percentage of totals

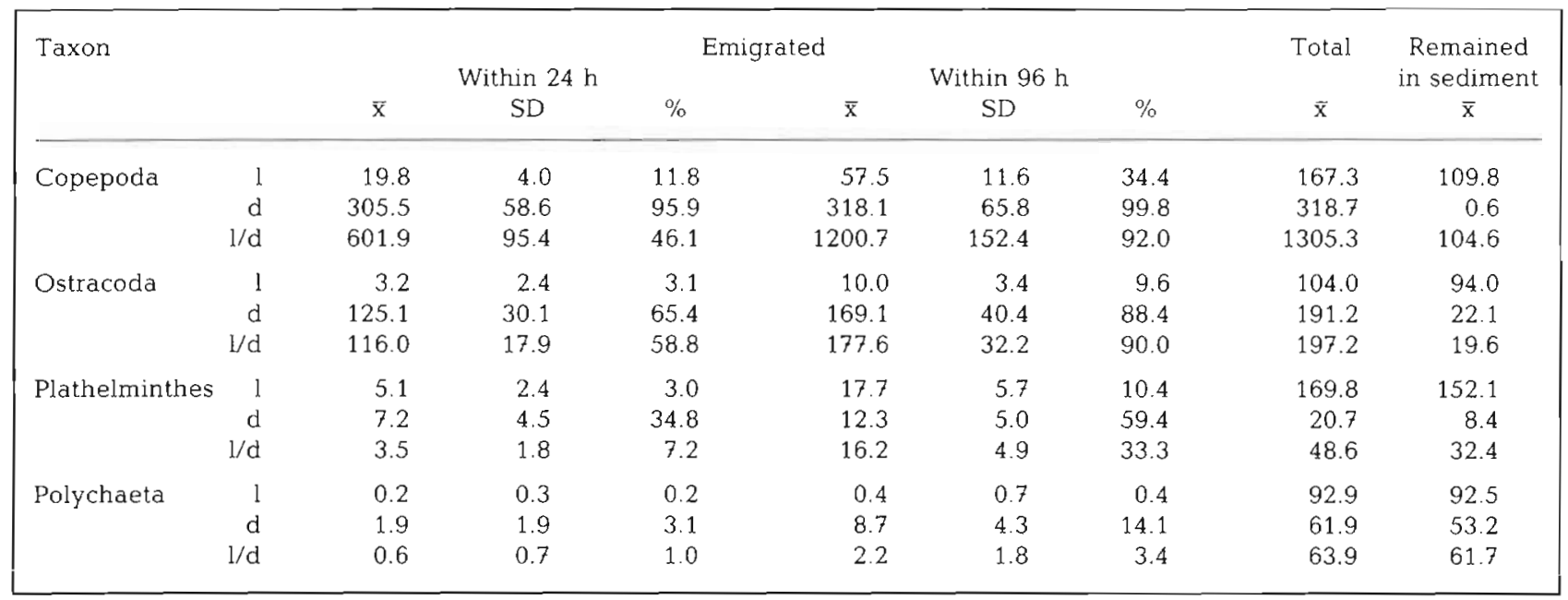

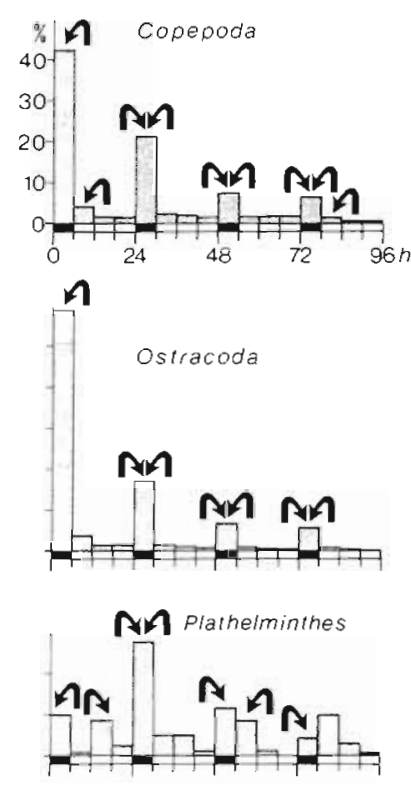

Fig. 1. Course of emigration during $4 \mathrm{~d}$ of submergence (Expt Ic, $18 / 6 \mathrm{~h} \mathrm{Light/dark}$ cycle). Percentages of the totally emigrated number of individuals per taxon. Arrows indicate a significant difference between succeeding periods ( $U$-test, $p<0.05)$. Decrease in numbers over time results from the emptying of sediment cores through emigration. Black and white fields below columns indicate darkness and light, respectively

small because of high numbers of nauplius-larvae (not included) and copepodites (included in copepods) in the sediment. Development of nauplius-larvae to copepodites increased the emigration rates of the final days and the totals.

Since Nematoda and Oligochaeta remained in the sediment while other taxa at least partly emigrated, the taxonomic composition of emigrated fauna is different from that of fauna remaining in the sediment (significant differences in the rank order of abundance; Fig. 2).

From Expt $\mathrm{I}$, the following conclusions can be derived:

(1) For the taxa Copepoda, Ostracoda, Plathelminthes and Polychaeta, $\mathrm{H}_{0}(1)$ is rejected. Members of these taxa actively emigrated from the sediment.

(2) In the case of Copepoda, Ostracoda and Plathelminthes, emigration shows a marked periodicity coinciding with and possibly caused by differences in the light regime. $\mathrm{H}_{0}(2)$ should therefore be rejected. However, based on the number of animals that stayed in the sediment up to a distinct point in time, the percentages of Ostracoda and Copepoda leaving the sediment per day do not significantly differ. In retrospect it seems a fairly constant percentage of copepods left the sediment per day, causing a continuous decrease in numbers. With regard to the percentage emigration, $H_{o}(2)$, hypothesising no differences in emigration among the $4 \mathrm{~d}$, is accepted.

(3) $H_{0}(3)$ is rejected. The percentage taxonomic composition in the sediment significantly differs from that of the emigrated fauna.

\section{Experiment II: Percentage emigration during one tidal cycle of submersion}

Altogether $87 \%$ of Copepoda, $67 \%$ of Ostracoda, and $42 \%$ of Plathelminthes left the sediment during a single simulated nocturnal high tide. The respective percentages were considerably smaller during a diurnal high tide (Fig. 3). All percentages should be regarded as minimum values: possibly some specimens 
Fig. 2. Changes in the rank order of taxa between the fauna of original sediment (not submerged but sorted immediately), emigrated fau$n a$, and the fauna remaining in the sediment after $4 \mathrm{~d}$ of submersion (Expt Ib). Ranks are based on significant differences in abundance ( $U$-test)

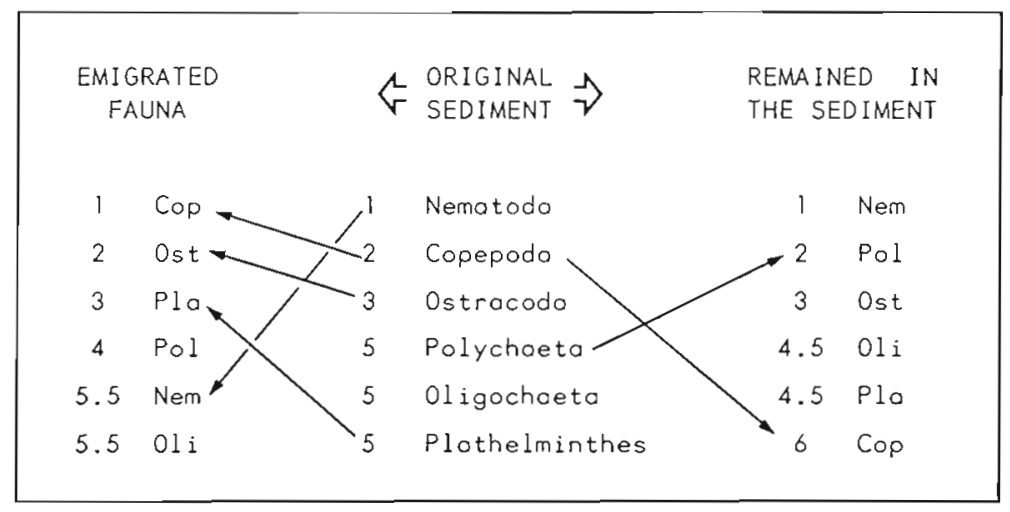

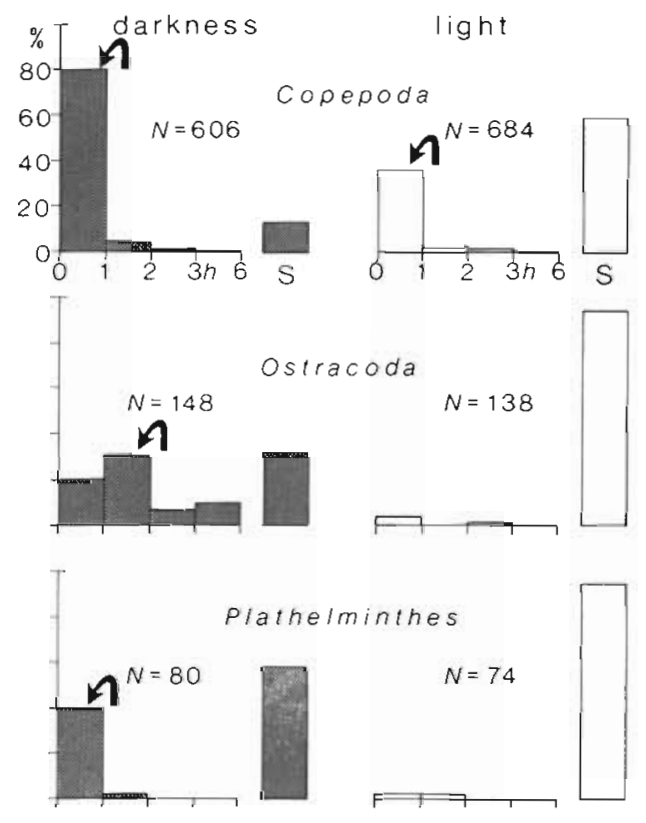

Fig. 3. Course of emigration during 6 h of submersion (Expt II). Percentages of total abundance $\left(N\right.$ ind. $\left.10 \mathrm{~cm}^{-2}\right)$. S: percentage remaining in the sediment. Because of low abundance the period 3 to $6 \mathrm{~h}$ is combined. Arrows indicate significant difference between successive periods

emerged from the sediment but returned prior to sampling. Calculating from the base areas of the glass jars $\left(2.5 \mathrm{~cm}^{2}\right)$ and aquaria $\left(50 \mathrm{~cm}^{2}\right)$, the probability of a swimming animal returning accidentally to the inner glass jars with sediment is about $5 \%$. Since the natural sediment might be more attractive than a bare plastic ground, the degree of underestimation may even be higher than $5 \%$.

Copepoda and Plathelminthes show maximum emigration rates during the first hour of submersion (Fig. 3 ). Ostracods need more time to climb out of the glass jars. This might either indicate a true delay in their activity, or might be an artifact of the unnatural glass container. However, in all cases considerable numbers of animals emerge during $1 \mathrm{~h}$ of submergence without currents. During slack tides, there are periods of similar length without strong currents in the field, and corresponding emergence of these taxa is expected. $\mathrm{H}_{0}(4)$, hypothesising a random pattern of emigration over $6 \mathrm{~h}$, is rejected.

\section{Experiment III: Distance meiobenthos swims above the bottom}

Although Ostracoda were highly active under comparable conditions in Expts I and II they were only once found in a submerged box. There is no hint that Ostracoda are able to swim actively. Among the active swimmers, only Copepoda and Plathelminthes were in sufficient numbers for a statistical evaluation. Abundance of Copepoda did not significantly differ between the boxes fixed between 10 and $50 \mathrm{~cm}$ above ground (Fig. 4). In the case of Plathelminthes the uppermost box contained fewer individuals, which is significant on a $5 \%$ level, but not significant when $p$ is adjusted to an adequate level for 10-fold multiple comparisons. There was no difference between the other heights. Thus, concerning Copepoda and Plathelminthes, $\mathrm{H}_{\mathrm{o}}$ (5) is maintained.

\section{Experiment IV: Specific composition of emigrating and non-emigrating Plathelminthes and Polychaeta}

In Expt Ib, sediment samples were submerged and significant numbers of Plathelminthes swam out into the water column. After $4 \mathrm{~d}$, all samples were sorted for the benthos that remained in the sediment. Comparing the numbers of emigrators versus non-emigrators, significant differences appear between taxa as well as trophic groups (Table 2). Significantly more Proseriata, Typhloplanoida and Dalyellioida emerged from the sediment while more Kalyptorhynchia rested in the sediment. On the species level, Promesostoma meixneri Ax, 1951, Pogaina suecica (Luther, 1948), Provor- 


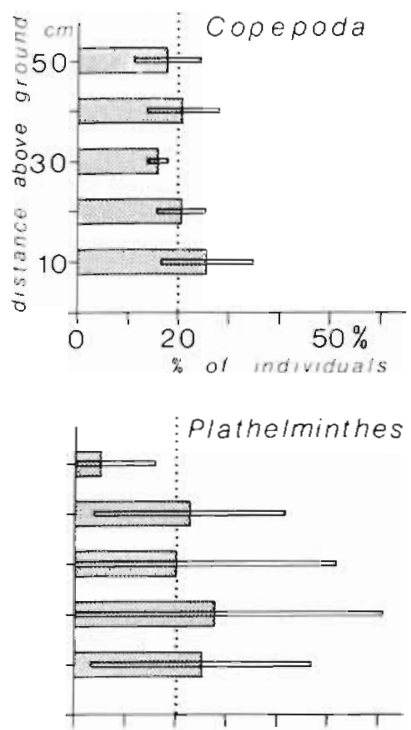

Fig. 4. Distribution of Copepoda and Plathelminthes over boxes submerged in barrels (percentages per height, standard deviation; Expt III). Dotted line: $20 \%$ level expected in the case of completely regular distribution over the entire range

tex tubiferus Luther, 1948, Provortex psammophilus Ax, 1951 and Cheliplanilla caudata Meixner, 1938 all emigrated in significant numbers. Bresslauilla relicta Reisinger, 1929 and Neoschizorhynchus parvorostro Ax $\&$ Heller, 1970 on the other hand, preferred to remain in the sediment during the $4 \mathrm{~d}$ of submersion.

Much of this variability is explained by the type of feeding (Table 2). The majority of copepods emigrated from the sediment, and copepod-feeding Plathelminthes did the same. Correspondingly, no nematode emigration was observed, and most of the nematodefeeding Platheiminthes stayed in the sediment just as did bacteria-feeders. Diatom-feeders and unspecific predators on meiofauna and microfauna preferred to leave the sediment.

Because of low abundance, no significant correlations were found between polychaete emergence and their feeding-types. However, there were specific differences in the emigration rates. Juvenile (mostly $<1 \mathrm{~cm}$ long) Nereis diversicolor O.F. Müller emigrated in the highest percentage, followed by Eteone longa (Fabricius). Anaitides mucosa (Oersted) and Pygospio elegans Claparède were already scarce and others, such as Scoloplos armiger (O. F. Müller), which is the dominant polychaete at the investigated site, were never found in the water column.

\section{DISCUSSION}

\section{Behavioral versus physically forced emergence}

This study revealed 2 causal factors urging benthos to enter the water column: (1) Most of the emerged harpacticoids and Plathelminthes left the sediment immediately after submersion. Significant differences in the course of emigration indicate that emergence is not just a casual event in these taxa but seems to be regular, possibly triggered by endogenous factors. (2)

Table 2. Plathelminth taxa that showed significant differences between abundance in water column (emigrators) and in sediment (non-emigrators) after $4 \mathrm{~d}$ of submersion in the dark (Expt Ib). $\mathrm{x}$ : Average abundance per $10 \mathrm{~cm}^{2}$ of sediment surface; SD: standard deviation $; \cdots, \cdots$ Significance level (U-test, $p<0.05,0.01,0.001$ respectively). Non-significant comparisons are omitted. B, C, $D, N$, P: feeding types (see below)

\begin{tabular}{|c|c|c|c|c|}
\hline \multirow[t]{2}{*}{ Taxon and feeding types } & \multicolumn{2}{|c|}{ Emigrators } & \multicolumn{2}{|c|}{ Non-emigrators } \\
\hline & $\mathrm{x}$ & $\mathrm{SD}$ & $\mathrm{x}$ & $\mathrm{SD}$ \\
\hline Proseriata $(P)$ & 1.3 & $1.42^{*}$ & 0 & \\
\hline Typhloplanoida (mostly C) & 1.7 & $1.16^{*}$ & 0.3 & 0.48 \\
\hline Promesostoma meixneri (C) & 1.1 & $1.37^{*}$ & 0 & \\
\hline Kalyptorhynchia ( $\mathrm{B}$ and $\mathrm{N}$ ) & 0.5 & 0.53 & 3.7 & $2.31^{\cdots}$ \\
\hline Cheliplanilla caudata $(\mathrm{N})$ & 0.5 & $0.53^{\circ}$ & 0 & \\
\hline Neoschizorhynchus parvorostro (B) & 0 & & 1.8 & $1.32 \cdots$ \\
\hline Dalyellioida (D, B and P) & 7.9 & $3.78^{\circ}$ & 4.2 & 2.53 \\
\hline Pogaina suecica $(D)$ & 4.0 & $3.13 \cdots$ & 0.3 & 0.67 \\
\hline Bresslauilla relicta (B) & 0.2 & 0.42 & 1.9 & $1.45^{*}$ \\
\hline Provortex tubiferus (D) & 1.6 & $1.35^{\cdots}$ & 0 & \\
\hline Provortex psammophilus (P) & 0.8 & $0.63^{\cdots}$ & 0.1 & 0.32 \\
\hline \multicolumn{5}{|l|}{ Feeding types: } \\
\hline D Diatom-feeders & 7.6 & $3.86^{\cdots}$ & 2.4 & 1.43 \\
\hline B Bacteria-feeders & 0.2 & 0.42 & 3.7 & $2.54 \cdots$ \\
\hline C Copepod-feeders & 1.5 & $1.35^{\circ}$ & 0.2 & 0.42 \\
\hline N Nematode-feeders & 0.5 & 0.53 & 1.7 & $1.34^{\circ}$ \\
\hline P Unspecific predators & 2.2 & $1.55^{\cdots}$ & 0.1 & 0.32 \\
\hline
\end{tabular}


In the polychaete Pygospio elegans emigration occurred only after $1 \mathrm{~d}$ of submersion and was possibly caused by deterioration of environmental factors. This might also be the cause for the significantly higher number of Plathelminthes that left the glass jars after the sediment had been turned upside down. Further deterioration of physical factors such as oxygen content in experiments longer than $4 \mathrm{~d}$ might lead to emergence of additional taxa (cf. Lorenzen et al. 1987).

The rapid emigration during the first 1 to $2 \mathrm{~h}$ of experimental submersion in Copepoda, Plathelminthes and Ostracoda indicates that deterioration of physical factors is not the cause for their emergence - or else the physical factors had already been extremely unfavourable in the field. However, as indicated by the effect of light (Fig. 1), physical factors such as the light regime, oxygen availability, and salinity do influence emigration rates (Armonies unpubl.), and biotic factors might similarly be involved.

The 'laboratory environment' may be another factor influencing emigration rates. Although the effects of mechanical destruction of the sediment structure do not indicate that the sampling procedure was harmful, there is so far no adequate test for other factors.

All of the experiments described above were performed in the absence of flow. However, flow as well as other hydrodynamic factors like hydrostatic pressure may strongly influence the behavior of meiobenthos (e. g. Boaden 1968, Fegley 1987). Therefore further experiments were conducted to test for differences in the emigrative behavior in gradients of physical factors such as temperature, salinity and flow (Armonies unpubl.). Results indicate that emergence is not an artifact of the no-flow conditions, although the emergence pattern is indeed influenced by flow.

As a result of varying degrees of environmental harshness and specific differences in the tendency to leave the sediment, a regular gradient is expected between plankton occasionally touching the sediment and benthos occasionally emerging from the sediment. On such a scale, Nematoda are relatively benthic and most Copepoda are relatively planktonic. However, this classification only meets the situation in the studied intertidal sand flat. On more exposed beaches epibenthic harpacticoids become rare (Mielke pers. comm.), and interstitial species might be more benthic. The fauna of muddy sites, on the other hand, seems to include some good as well as bad swimmers (Palmer 1984)

In Plathelminthes and Polychaeta it seems that the emergence rates can roughly be estimated by the swimming ability of the respective species (observation of the swimming ability in Petri dishes after mechanical stimulation). Some differences also exist in copepods: the slender interstitial species tend to emigrate less rapidly than do the more voluminous epibenthic harpacticoids. Bell et al. (1987) reported on significant correlations between morphological indices and the habitat utilization and type of movement in seagrass harpacticoids

\section{Consequences of emigration on distributional patterns}

As a consequence of active emigration from the sediment, short-term temporal variations in abundance and population structure are expected, and for harpacticoids have already been demonstrated by Kern \& Bell (1984). Specific differences in the tendency to leave the sediment (as demonstrated in Polychaeta and Plathelminthes) may also cause short-term changes in the faunal composition. Tischler (1979, p. 125) proposed differentiating any list of species obtained from a single habitat according to categories such as 'indigenous species', 'visitors', and 'guests'. In the light of high meiobenthic mobility, this suggestion seems also to be appropriate for meiobenthic organisms, especially in community studies and environmental monitoring.

\section{Potential benefits versus potential risk of emersion}

In Expt II ( $6 \mathrm{~h}$ submersion in the dark) an average of 48 copepods emigrated per $1 \mathrm{~cm}^{2}$ of sediment surface during the first hour of submersion (Fig. 2). Since the period of swimming activity of a single specimen is not known, the actual abundance of benthos in the water column can only be estimated: provided a single specimen swims no longer than 5 min, up to 40000 copepods $\mathrm{m}^{-2}$ are simultaneously active in the water column. Likewise, if the swimming period is only $1 \mathrm{~min}$ 8000 harpacticoids above $1 \mathrm{~m}^{2}$ of sediment surface should be attractive enough to be a remunerative source of food, e. g. for juvenile fish (Alheit \& Scheibel 1982, Pihl \& Rosenberg 1984, Pihl 1985). Small sizeclasses of the goby Pomatoschistus minutus (Pallas) even seem to prefer benthic harpacticoids to planktonic calanoids (Zander \& Hagemann 1987). Possibly the benthic harpacticoids are easier to catch than calanoids. The higher nocturnal than diurnal swimming activity may be useful in avoiding visual predators (Hobson \& Chess 1976, Greening \& Livingston 1982, Ohlhorst 1982, Fancett \& Kimmerer 1985) and the joint emergence of many specimens during a restricted period may be another way to reduce each individual's risk of being preyed upon.

Additional prey (Decho 1986) and the possibility of dispersal are advantages of emergence. Species with a high rate of emersion might additionally increase their 
abundances from a small-scale towards a larger-scale carrying capacity and thus more intensively exploit resources (see Thistle 1980). Possibly emergence can also help to escape predation within the sediment. The high rates of emergence, despite the risk of being preyed upon, indicate alone that there must be a net advantage in regularly leaving the sediment, or, at least, no disadvantage.

\section{Emergence increases the stability of the benthic system}

From an ecosystem point of view, emergence from the sediment is regarded as an efficient way of energy exchange between the benthos and pelagial. A high abundance of food items in the water column can be transferred to the benthos even before being sedimented and an exceptionally high abundance of swimming benthos will presumably increase the rate of predation by pelagic predators. Small-scale disturbances of the benthic system may likewise be rapidly compensated for (e. g. Sherman \& Coull 1980, Thistle 1980, Hockin \& Ollason 1981, Palmer \& Brandt 1981, Chandler \& Fleeger 1983). Thus, high mobility may increase the persistence of the benthic system and its ability to absorb changes and disturbance and still maintain the same relationships between species or state variables (= resilience; Holling 1973).

Acknowledgements. Expt I could not have been carried out without the help of Monika Hellwig-Armonies. Karsten Reise improved the manuscript by critical comments. This study was supported by a grant of the Biologische Anstalt Helgoland

\section{LITERATURE CITED}

Alheit, J., Scheibel, W. (1982). Benthic harpacticoids as a food source for fish. Mar. Biol. 70: 141-147

Alldredge, A. L., King, J. M. (1977). Distribution, abundance, and substrate preferences of demersal reef zooplankton at Lizard Island lagoon, Great Barrier Reef. Mar Biol. 41: 317-333

Alldredge, A. L., King, J. M. (1980). Effects of moonlight on the vertical migration patterns of dermersal zooplankton. J. exp. mar Biol. Ecol. 44: 133-156

Alldredge, A. L., King, J. M. (1985). The distance demersal zooplankton migrate above the benthos: implications for predation. Mar. Biol. 84: 253-260

Bell, S. S., Sherman, K. M. (1980). A field investigation of meiofaunal dispersal: tidal resuspension and implications. Mar Ecol. Prog. Ser. 3: 245-249

Bell, S. S., Walters, K., Hall, M. O. (1987). Habitat utilization by harpacticoid copepods: a morphometric approach. Mar. Ecol. Prog. Ser. 35: 59-64

Boaden, P. J. S. (1968). Water movement - a dominant factor in interstitial ecology. Sarsia 34:125-136
Boaden, P. J. S., Platt, H. M. (1971). Daily migration patterns in an intertidal meiobenthic community. Thalassia jugosl. 7 . $1-12$

Chandler, G. T., Fleeger, J. W. (1983). Meiofaunal colonization of azoic sediment in Louisiana: mechanisms of dispersal. J. exp. mar. Biol. Ecol. 69: 175-188

Decho, A. W. (1986). Water-cover influences on diatom ingestion rates by meiobenthic copepods. Mar. Ecol. Prog. Ser. 33: 139-146

Fancett, M. S., Kimmerer, W. J. (1985). Vertical migration of the demersal copepod Pseudodiaptomus as a means of predator avoidance. J. exp. mar. Biol Ecol. 88: 31-43

Fegley, S. R. (1987). Experimental variation of near-bottom current speeds and its effect on depth distribution of sandliving meiofauna. Mar. Biol. 95: 183-191

Fleeger, J. W., Chandler, G. T., Fitzhugh, G. R., Phillips, F. E. (1984). Effects of tidal currents on meiofauna densities in vegetated salt marsh sediments. Mar. Ecol. Prog. Ser. 19: 49-53

Fulton, R. S. (1982). Predatory feeding of two marine mysids Mar. Biol. 72: 183-191

Gerlach, S. A. (1977). Means of meiofauna dispersal. Mikrofauna Meeresboden 61: 89-103

Greening, H. S., Livingston, R. J. (1982). Diel variation in the structure of seagrass-associated epibenthic macroinvertebrate communities. Mar. Ecol. Prog. Ser. 7: 147-156

Hagermann, G. M., Rieger, R. M. (1981). Dispersal of benthic meiofauna by wave and current action in Bogue Sound, North Carolina, USA. P.S.Z.N.I.: Mar. Ecol. 2: 245-270

Hammer, R. M. (1981). Day-night differences in the emergence of demersal zooplankton from a sand substrate in a kelp forest. Mar. Biol. 62: 275-280

Hicks, G. R. F. (1986). Distribution and behaviour of meiofaunal copepods inside and outside seagrass beds. Mar Ecol. Prog. Ser. 31: 159-170

Hobson, E. S., Chess, J. R. (1976). Trophic interactions among fishes and zooplankters near shore at Santa Catalina Island, California. Fish. Bull. U. S. 74: 567-598

Hobson, E. S., Chess, J. R. (1979). Zooplankters that emerge from the lagoon floor at night at Kure and Midway atolls, Hawaii. Fish Bull. U. S. 77: 275-280

Hockin, D. C., Ollason, J. G. (1981). The colonization of artificially isolated volumes of intertidal estuarine sand by harpacticoid copepods. J. exp. mar. Biol. Ecol. 53: 9-29

Holling, C. S. (1973). Resilience and stability of ecological systems. Ann. Rev. ecol. Syst. 4: 1-23

Kern, J. C., Bell, S. S. (1984). Short-term temporal variation in population structure of two harpacticoid copepods, Zausodes arenicolus and Paradactylopodia brevicornis. Mar. Biol. 84: 53-63

Lorenzen, S., Prein, M., Valentin, C. (1987). Mass aggregations of the free-living marine nematode Pontonema vul gare (Oncholaimidae) in organically polluted fjords. Mar. Ecol. Prog. Ser. 37: 27-34

McWilliam, P. S., Sale, P. F., Anderson, D. T (1981). Seasonal changes in resident zooplankton sampled by emergence traps on One Tree Lagoon, Great Barrier Reef. J. exp. mar. Biol. Ecol. 52: 185-203

Meineke, T., Westheide, W. (1979). Gezeitenabhängige Wanderungen der Interstitialfauna in einem Sandstrand der Insel Sylt (Nordsee) Mikrofauna Meeresboden 75: 1-36

Ohlhorst, S. L. (1982). Diel migration patterns of demersal reef zooplankton. J. exp. mar Biol Ecol. 60: 1-15

Palmer, M. A. (1984). Invertebrate drift: behavioral experiments with intertidal meiobenthos. Mar. Behav. Pyhsiol 10: $235-253$

Palmer, M. A. (1986). Hydrodynamics and structure: interac- 
tive effects on meiofauna dispersal. J. exp. mar. Biol. Ecol. 104: 53-68

Palmer, M. A., Brandt, R. R. (1981). Tidal variation in sediment densities of marine benthic copepods. Mar. Ecol. Prog. Ser 4: $207-212$

Palmer, M. A., Gust, G. (1985). Dispersal of meiofauna in a turbulent tidal creek. J mar Res, 43: 179-210

Palmer, M. A., Molloy, R. M. (1986). Water flow and the vertical distribution of meiofauna: a flume experiment. Estuaries 9: 225-228

Pihl, L. (1985). Food selection and consumption of mobile epibenthic fauna in shallow marine areas. Mar. Ecol. Prog Ser. 22: 169-179

Pihl, L., Rosenberg, R. (1984). Food selection and consumption of the shrimp Crangon crangon in some shallow marine areas in western Sweden. Mar. Ecol. Prog. Ser 15: 159-168

Porter, J. W. Porter, K. G. (1977). Quantitative sampling of demersal plankton migrating from different coral reef substrates. Limnol. Oceanogr. 22: 553-556

Reise, K. (1985). Tidal flat ecology. Springer, Berlin

Sachs, L. (1984). Angewandte Statistik. Springer, Berlin

Sherman, K. M., Coull, B. C. (1980). The response of meiofauna to sediment disturbance. J. exp. mar. Biol. Ecol. 46: $59-71$
Sibert, J. R. (1981). Intertidal hyperbenthic populations in the Nanaimo Estuary. Mar. Biol. 64: 259-265

Sogard, S. M. (1984), Utilization of meiofauna as a food source by a grassbed fish, the spotted dragonet Callionymus pauciradiatus. Mar. Ecol. Prog. Ser. 17: 183-191

Thistle, D. (1980). The response of a harpacticoid copepod community to a small-scale natural disturbance. J. mar. Res. 38: 381-394.

Tischler, W. (1979). Einführung in die Ökologie. Fischer, Stuttgart

Walters, K., Bell, S. S. (1986). Diel patterns of active vertical migration in seagrass meiofauna. Mar. Ecol. Prog. Ser. 34: 95-103

Youngbluth, M. J. (1982). Sampling demersal zooplankton: a comparison of field collections using three different emergence traps. J. exp. mar. Biol. Ecol. 61: 111-124

Zander, C. D., Hartwig, E. (1982). On the biology and food of small-sized fish from North and Baltic Sea areas. IV. Investigations on an eulittoral mud flat at Sylt Island. Helgoländer Meeresunters. 35: 47-63

Zander, C. D., Hagemann, T. (1987). Predation impact and ecological efficiency of Pomatoschistus spp. (Gobiidae, Pisces) from a clay/sand ecotone of the western Baltic Sea. Zool. Anz. 218: 33-48

This article was submitted to the editor; it was accepted for printing on January 8,1988 